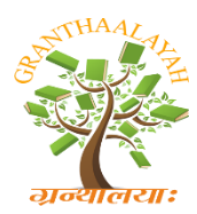

Social

\title{
THE USE OF INQUIRY-BASED STUDENT WORKSHEET TO INSTILLS SCIENCE GENERIC SKILL OF THE STUDENTS
}

\author{
Nurul Khabibah ${ }^{1}$, Tri jalmo ${ }^{2}$, Agus Suyatna ${ }^{2}$ \\ ${ }^{1}$ Graduate Student of Physics Education, University of Lampung, Indonesia \\ ${ }^{2}$ Lecturer of Physics Education, University of Lampung, Indonesia
}

\begin{abstract}
This research aims to develop inquiry-based student worksheet and to describe its attractiveness, usefulness and effectiveness. The development design uses seven steps of Borg \& Gall research including research and data collection, planning, product draft development, initial field testing, revision of the test results, field testing, and product improvement. Product validation includes material validation, design and content using questionnaires. The subjects of the testing are teachers and students of one of state senior high schools in East Lampung. The results of material validation, design and student worksheet's content are included in high category, so that it can be stated that the student worksheet is worth to use. The results of field testing indicated that inquirybased student worksheet can instill students' science generic skills in static fluid subject. Teachers' and students' responses towards the development results were $78 \%$ which was categorized as very attractive and $78 \%$ as very useful. From the results of effectiveness test, it was known that posttest values was higher than the mean of pre-test value. Therefore, the product which has been developed in the form of inquiry-based student worksheet is effective to instill science generic skill of the students.
\end{abstract}

Keywords: Student Worksheet; Inquiry; Science Generic Skill.

Cite This Article: Nurul Khabiba, Tri jalmo, and Agus Suyatna. (2018). "THE USE OF INQUIRY-BASED STUDENT WORKSHEET TO INSTILLS SCIENCE GENERIC SKILL OF THE STUDENTS." International Journal of Research - Granthaalayah, 6(6), 131-138. https://doi.org/10.29121/granthaalayah.v6.i6.2018.1358.

\section{Introduction}

Twenty-first-century learning emphasizes the ability of learners in finding information from various sources, formulate problems, think analytically as well as cooperate and collaborate in solving problems ( $\mathrm{R} \& \mathrm{D}$ of The Ministry of Education and Culture, 2013). Therefore, in order to solve the existing problems, it requires a medium, and student worksheet is one of many media used in teaching and learning process in the school. Student worksheet is very important to be a guide to conduct investigation and problem-solving activities. Student worksheet contains 
assignments with the topics which are aligned with learning objectives and activities (Nyamupangedengu \& Lelliot, 2012).

Student worksheet is used as a means for teachers to increase student involvement in teaching and learning activity. Therefore, the students can play a more active role which can turn teachercentered learning into student-centered learning with the help of student worksheet. Based on pilot study on the results of field observation, there are teachers who still conduct learning in the classroom which is dominated by using lecture method. The method used by a teacher has an impact on students' understanding towards concepts and learning (Kitot, et al, 2010)

One of the learnings that can be applied in student worksheet is inquiry-based learning. Inquiry learning model is a model of learning that can produce smart and insightful students (Mulyasa, 2007), inquiry model encourages students to be able to solve problems and play an active role in the process of science. This was also suggested by Kitot et al. (2010) that inquiry-based learning plays an important role in solving problems. The use of inquiry-based learning has been used since 1950s and 1960s in the United States where more focus is given on problem-solving activities (Arends, 2001). According to Mulyasa, (2007) Inquiry-based learning is a model of inquiry which is involving mental processes with activities such as asking questions about natural phenomena, formulating problems which are found, formulating hypotheses, designing and conducting experiments, collecting and analyzing data, and drawing conclusions. According to Mareta, et al (2012) the physics subject is an experimental lesson, so it is good if the learning is supported by the experiments which are conducted by teachers or students in a guided manner.

Physics subject is a lesson which can instill of thinking pattern, working pattern and scientific attitude (Department of National Education, 2014). Science Generic Skill is the basic (generic) skill needed to train students' scientific works. (Brotosiswoyo, 2001). Science generic skill is becoming increasingly important in life, especially in the current era of globalization (Zainal, et al, 2011) Science Generic Skill has a very important role in improving students' understanding of existing theories and concepts of physics and in supporting learning by emphasizing the process and science products.

\section{Methodology}

The research method used in this research was Research and Development method by Borg \& Gall (1983) which stated that there are 10 steps. The implementation of a development research strategy, as outlined by Borg \& Gall (1983) includes Research and data collection; Planning; Product draft development; Product testing (validation); Product revision; Field test; Final product improvement; Field test implementation; Final product completion; Dissemination and implementation. From those ten steps developed by Borg and Gall, the implementation in this research was limited to the seventh step. In the field test step, final product improvement and dissemination was not conducted because this step takes long time and higher cost.

The instrument used for data collection in this development was questionnaires. The questionnaires consisted of two types, namely lecturers and teachers validation questionnaires and student assessment questionnaires. Each questionnaire contained assessment scores and comments or suggestions towards the student worksheet which has been developed. In the questionnaire 
instrument of experts' validation test assessment, the product assessment by the validators was performed by giving the scores 1 and 2 in accordance to Guttmann scale guidance.

The product effectiveness test used special test in the form of pre-test and post-test, then it performed statistical analysis using Mann Whitney Test. This test aims to see whether there is an increase in student learning out comes after using the product as the result of the development. The design of this research is presented as in the Table 1 below.

Table 1: Research Design

\begin{tabular}{|l|l|l|l|}
\hline Experiment & $\mathrm{O}_{1}$ & $\mathrm{X}_{1}$ & $\mathrm{O}_{2}$ \\
\hline Control & $\mathrm{O}_{3}$ & - & $\mathrm{O}_{4}$ \\
\hline
\end{tabular}

Information

\begin{tabular}{|l|l|}
\hline$O_{1}$ & Prettest of experimental group \\
\hline$O_{3}$ & Prettest of control group \\
\hline$X$ & The treatment which is given (variable independent) \\
\hline$O_{2}$ & Posttest of experimental group \\
\hline$O_{4}$ & Posttest of control group \\
\hline
\end{tabular}

The hypothesis test used the comparison of two means in this study which was conducted by using t-test of two independent samples. The statistical hypothesis formula of this test is as follows:

$$
\begin{aligned}
& H_{0}: \mu_{1} \leq \mu_{2} \\
& H_{1}: \mu_{1}>\mu_{2}
\end{aligned}
$$

$H_{0}$ is the mean score of the control group which is equal or smaller than the mean score of experimental group while is the mean score of experimental group which is bigger than the mean score of control group. The basic decision making is based on the criteria of rejecting or not rejecting score, if $\mathrm{P}$-value < then is rejected and if $\mathrm{P}$-value then is accepted.

The improvement of science generic skill before and after learning activities is calculated using the formula (Hake, 2002):

$$
<g>=\frac{\%<S_{\text {post }}>-\%<S_{\text {pre }}>}{100-\%<S_{\text {pre }}>} x 100 \%
$$

This Gain value which has been normalized is interpreted in order to express the developed science generic skill in static fluid with the criteria as shown in the Table 2 below.

Table 2: Normalized Gain Level Category

Source: (Hake, 2002)

\begin{tabular}{|l|l|}
\hline Limitation & Category \\
\hline$\langle g\rangle>0,7$ & High \\
\hline $0,3 \leq<g\rangle \leq 0,7$ & Moderate \\
\hline$\langle g\rangle\langle 0,3$ & Low \\
\hline
\end{tabular}




\section{Results and Discussions}

Student worksheet which has been developed contains activity step based on steps at early stage of student worksheet that presents phenomenon related to static fluid subject to the stage that presents formulation of the problem, students are demanded to make hypothesis. Then, at the stage to conduct the experiment, the students are presented with the tools and materials which will be used to conduct the testing/experiment, and after that, the students analyze the data obtained through the experiment and draw the conclusion. At the application stage, the students are demanded to present the results of the experiment. Those stages used guided inquiry learning model. The stages in the student worksheet which has been developed adapted Hanson (2006) and Pedaste, et al (2015).

According to Hanson (2006). At each guided inquiry stage, the students will show various indicators of science generic skill. Those stages are supported by (Katchevich, et al, 2011) and Hanson (2006) which include: presenting a phenomenon, making research questions, writing the hypotheses, planning an experiment to test the hypotheses, after collecting the data, analyzing and interpreting the results, drawing the conclusion, and expressing opinions.

The results of validity test on student worksheet products are conducted by the expert lecturer and practitioners by giving the assessment to the questionnaires. The results of test assessment of product content and design validity experts which has been developed are listed in the Table 3 .

Table 3: The Results of Experts Test Assessment

\begin{tabular}{|l|l|l|l|l|}
\hline No & Validator & Type of the test & Score Percentage & Qualitative Statement \\
\hline $\mathbf{1}$ & Expert 1 & Content & 70.58 & Good \\
\hline & & Design & 77.77 & Very Good \\
\hline $\mathbf{2}$ & Expert 2 & Content & 70.58 & Good \\
\hline & & Design & 55.55 & Good \\
\hline $\mathbf{3}$ & Expert 3 & Content & 88.23 & Very Good \\
\hline & & Design & 94.44 & Very Good \\
\hline
\end{tabular}

From the results of content validity test, it is obtained that the mean percentage is 76 , which means that the feasibility of the contents of the student worksheet is in the category of very good to use. While, according to the design validation, it is obtained that the mean percentage is 76 which means that the feasibility of graphical aspects, language and presentation of the student worksheet is in very good category, but it still needs improvement.

The next step is to test the product to the physics teachers and high school students. The test of product usage is conducted by filling the questionnaires about it attractiveness and usefulness. From the results of the student worksheet attractiveness test, it got high score category which means that it is interesting/attractive. The indicators of attractiveness assessment are viewed based on the cover, drawings and illustrations in the student worksheet, as well as the opening material of the student worksheet.

The display of the cover has a more varied color combination, it is supported by the display of the phenomena pictures which are in accordance with the materials that will be studied which make 
the teachers attracted to explain them to the students. According to Yasir, et al (2013), a good student worksheet's display is supported by color variations, images, and phenomena descriptions, so it will attract students' attention.

The usefulness test acquired a score of 3.13 with a high category, which means that it is useful. It is said to be useful because: this student worksheet provides an opportunity to carry out learning by using guided inquiry model. It is because all this time, teachers feel less trained to apply learning models without the existing guidance, in this case is student worksheet. This is in accordance with the statement of (Ozdemir \& Isik, 2015) that the quality and ability of science teachers are things that become the obstacles and limitations faced by science teachers in implementing inquiry-based learning, so that the guidance in the form of a student worksheet is needed.

The effectiveness of the product is acquired through the field test, according to it, it obtained an information that the use of inquiry-based student worksheet instill science generic skill of the students. The testing on inquiry-based student worksheet products were conducted at Stated Senior High School, East Lampung. The score collection was through pre-test and post-test, and the statistical analysis used Mann Whitney Test because the data are not normally distributed. This test aims to see whether there is an increase in student learning out comes after using the product which has been developed. The test results are shown in the Table 4.

Table 4: Test Results of the difference of posttest and N-gain of control group and experimental group

\begin{tabular}{|l|l|l|l|}
\hline \multirow{2}{*}{ Group } & \multicolumn{2}{|c|}{ Mean } & Wilcoxon Test $(\mathbf{P})$ \\
\cline { 2 - 3 } & Post test $(\overline{\boldsymbol{x}})$ & n-Gain $(\overline{\boldsymbol{x}})$ (Category) & \\
\hline $\begin{array}{l}\text { Control } \\
(\mathrm{n}=30)\end{array}$ & 75,23 & $\begin{array}{l}0,54 \\
\text { (Moderate) }\end{array}$ & $0,000^{*}$ \\
\hline $\begin{array}{l}\text { Experimental } \\
(\mathrm{n}=30)\end{array}$ & 79,83 & $\begin{array}{l}0,64 \\
\text { (Moderate) }\end{array}$ & $0,000^{*}$ \\
\hline mannwhitney test $(\mathrm{P})$ & $0,028^{*}$ & $0,011^{*}$ & \\
\hline
\end{tabular}

$*$ The difference is on the trust level of $95 \%$

Based on the Table 4. It is seen that there was KGS difference between experimental and control group where the $\mathrm{N}$-gain score of experimental group was 0,64>0,54 from the control group, it concludes that inquiry-based student worksheet is more effective to improve KGS than the conventional student worksheet. There were significant scores both on post-test of experimental and control group on the level of trust of $95 \%$, but the improvement of the experimental group was79,83 $>75,23$ from the control group. Those data conclude that the achievement of science generic skill of the students in the experimental group is better than the achievement of the control group.

Below is the improvement graphic of students' learning out comes and analysis which used the mean score of which obtained that the mean was 0.58 for control group and was 0.65 for experimental group which means that the score in the experimental group was higher. The statistical test results showed that there was a significant difference between $\mathrm{N}$-gain of the control group and experimental group which was on the level of trust of $95 \%$. 


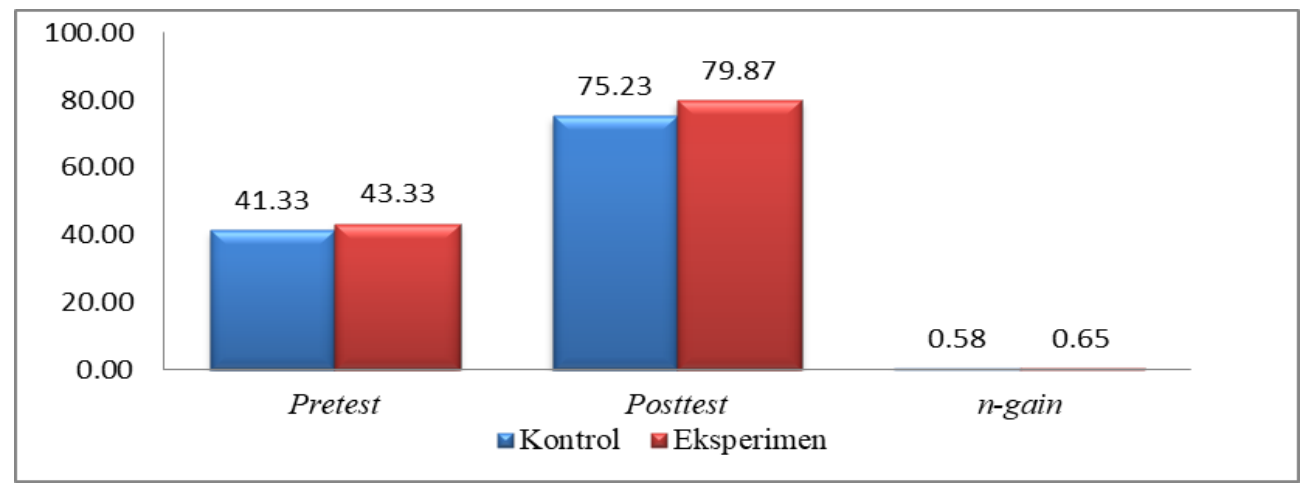

Figure 1: Learning Outcomes Mean Graph

This is possible to happen because in the experimental group, the learning activities are conducted through the experiments, the students have to play important role to prove the hypotheses that have been designed. At each guided inquiry step, the students are demanded to show the science generic skill. According to Maretaswari, et al, (2012) laboratory-based guided inquiry gives a significant influence towards the learning outcomes and scientific attitude of the students. While, according to Martineau, et al, (2013), the guided inquiry provides a significant impact in giving scientific experiences, instills students' beliefs in participating so that it is able to improve the skills of the students. It is in accordance with the research conducted by Wijayanti, et al (2010) which showed that guided inquiry learning can overcome students' learning difficulties. In addition, according to Kitot, et al (2010) inquiry learning has positive impact in stimulating students' thinking ability.

Product effectively test is also conducted to see the science generic skill of the students before and after using the product. The components of science generic skill which are assessed consist of six aspects namely direct observation, indirect observation, the awareness of the scale, symbolic language, logical consistency and causal law. Below is the results of the mean analysis of the students' science generic skill.

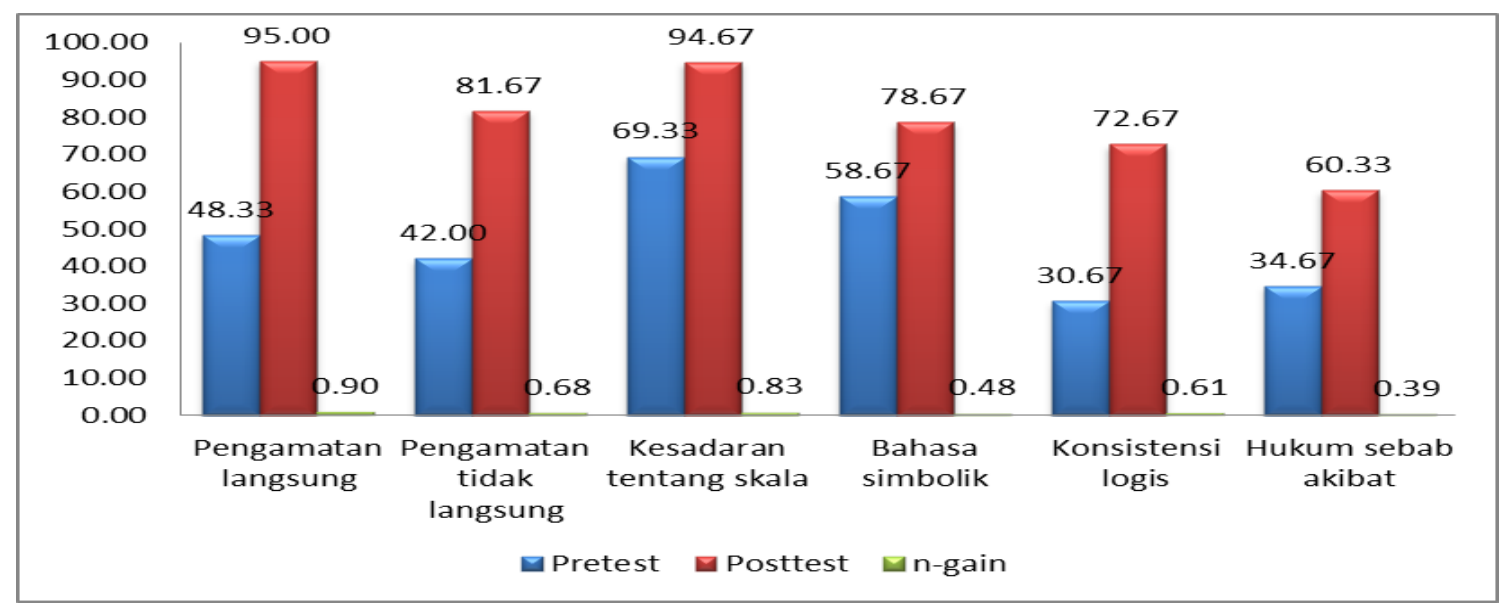

Figure 2: Analysis Results of Science Generic Skill Aspects Mean

Science generic skill acquired a mean score of 0.65 with moderate category on inquiry-based student worksheet effectively instills the science generic skill of the students. That indicates the existence of an increase after using the inquiry-based student worksheet. However, for causal law 
indicator, it gota score of 0.39 from six aspect which is the lowest score. From the low students' skill in the causal law, there are some factors that influence namely that in the learning process the students are not accustomed to provide a conclusion at the end. It is in accordance with the research conducted by Saptorini (2008) where the percentage of KGS on causal law indicator is 48,00\% with moderate category.

\section{Conclusion and Suggestion}

\subsection{Conclusion}

According to the discussion above, it can be concluded that: (1) Inquiry-based student worksheet which has been developed consists of title, Basic Competence indicators, student worksheet instructions, problem formulations, hypothesis making, experiment, analysis and conclusion drawing. At each inquiry step, the students will recognize the aspects of science generic skill starting from direct observation, indirect observation, the awareness of the scale, symbolic language, logical consistency and causal law (2) The student worksheet has high design and content validity, attractive category on the attractiveness of the questionnaires, useful category on the usefulness of the questionnaires.(3) The student worksheet which has been developed effectively instills the science generic skill of the students The learning out comes of the experimental group students are higher than the control group students'.

\subsection{Suggestion}

Based on the results of the research, the author suggests the inquiry-based student worksheet to instill science generic skill of XI grade of senior high school students on static fluid subject curriculum of 2013 could be a guide to study physics at schools.

\section{References}

[1] Arends, R.I. (2001). Learning to Teach (Ed.3). United State of America: McGraw Hill.Inc.

[2] Borg, W.L., and Gall, M.D. (1983). Educational Research: an introduction. London: Longman, Inc.

[3] Brotosiswoyo, B. S. (2001). Hakikat Pembelajaran MSAINS di Perguruan Tinggi Fisika. Pusat Antar Universitas Untuk Peningkatan Pengembangan Aktivitas Instruksional (PAU-PPAI), Jakata: Dirjen Dikti.

[4] Depdiknas. (2014). Permendikbud No 59 Tahun 2014 Lampiran III Kurikulum 2013 SMA/MA. Jakarta : Depdiknas

[5] Fatmasari, A., \& Supriyanto. (2015). Pengembangan LKS Praktikum Identifikasi Proses Pencernaan Hewan Ruminansia Berbasis Guided Inquiry di SMA. Unnes journal of Biology Education, 1-8

[6] Hake, Richard R. (2002). Analisyzing Change/Gain Scores. (Online). Tersedia di (http://www. Physics. Indiana. edu/ sdi/AnaliyzingChange-Gain.pdf), diakses pada 16 November 2015.

[7] Hanson, D. (2006). Instructor's Guide to Procces-Oriented Guided-Inquiry Learning. Stony Brook University-SUNY: Pacific Crest.

[8] Katchevich, D. Hofstein, A. \& Naaman,R. (2011). Argumentationin the Chemistry Laboratory: Inquiry and Confirmatory Experiments. Research Sains Education. 43: 317 - 345.

[9] Kitot, A. K. A., Ahmad, A. R., \& Seman, A. A. (2010). The effectiveness of inquiry teaching in enhancing students' critical thinking. Procedia-Social and Behavioral Sciences, 7, 264-273. 
[10] Maretasari, E., Subali, B., \& Hartono. (2012). Penerapan Model Pembelajaran Inkuiri Terbimbing Berbasis Laboratorium untuk Meningkatkan Hasil Belajar dan Sikap Ilmiah Siswa. Unnes Physics Education Journal, 27-31.

[11] Martineau, C., Traphagen, S., \&Sparkes , T. (2013). A Guided Inquiry Methodology to Achieve Authentic Science in a Large Undergraduated Biology Course. Journal of Biological Education, 240-245.

[12] Mulyasa, E. (2007) Menjadi guru yang profesional.Bandung: Remaja Rosdakarya

[13] Nyamupangedengu, E., \& Lelliott, A. (2012). An exploration of learners' use of worksheets during a science museum visit. African Journal of Research in Mathematics, Science and Technology Education, 16(1), 82-99.

[14] Ozdemir, O., \& Isik, H. (2015). Effect of Inquiry-Based Science Activities on Prospectivcess Skills and Inquiry StrategieseElemtary Teachers' Use of Science Pro. Journal of Turkish Science Education, 43-56.

[15] Pedaste, M., Mäeots, M., Siiman, L. A., De Jong, T., Van Riesen, S. A., Kamp, E. T.,\& Tsourlidaki, E. (2015). Phases of inquiry-based learning: Definitions and the inquiry cycle. Educational research review, 14, 47-61.

[16] Saptorini. (2008). Peningkatan Keterampilan Generik Sains bagi Mahasiswa Melalui Perkuliahan Praktikum Kimia Analisis Instrumen Berbasis Inkuiri. Jurnal Inovasi Pendidikan Kimia, 2, no. 1, h. 190-198.

[17] Yasir, M., Susantini, E., \& Wati, I. (2012). Pengembangan Lembar Kerja Siswa Berbasis Strategi Belajar Metakognitif untuk Meningkatkan Hasil Belajar Siswa Pada Materi Pewarisan Sifat Manusia. Jurnal Inkuiri, 266-275.

[18] Zainal, K., Hassan, W. Z. W., \& Alias, J. (2012). Generic skill level of UKM students after pursuing the compulsory general studies courses. Procedia-Social and Behavioral Sciences, 59, 558-564.

\footnotetext{
*Corresponding author.

E-mail address: Nurulkhabibah16@gmail.com
} 